\title{
Voluntary Environmental Disclosure and Corporate Performance: A Study of Quoted Consumer Goods Manufacturing Firms in Nigeria
}

\author{
Mudashiru A. Adebayo and Raymond A. Ezejiofor
}

\section{ABSTRACT}

This study examined the effect of voluntary environmental disclosure on the corporate performance of quoted consumer goods manufacturing firms in Nigeria. The study specifically examined the effect of voluntary disclosure on the current ratio and quick ratio. The study used the ex post facto research design. The population of the study was drawn from selected consumer good manufacturing firms quoted on the floor of the Nigerian Stock Exchange. The study was based on secondary sources of data, collected from annual financial reports. The study found that voluntary disclosure is positively related to the current ratio and a quick ratio of quoted manufacturing companies in Nigeria. The study recommended among others that to further fortify corporate governance practices among firms, there should be severe execution of Nigerian Stock Exchange sustainability disclosure guidelines for manufacturing firms.

Keywords: corporate performance, current ratio, quick ratio, voluntary environmental disclosure.

\section{INTRODUCTION}

Annual reports are the main source of mandatory and voluntary corporate disclosures (Wanjau, 2015). Disclosure refers to a whole array of different forms of information (Solomon, 2013); and serves as a means of communicating a firm's corporate performance to outsiders (Abraham \& Tonks, 2006). Corporate disclosure helps reduce uncertainty (Alhazaimeh, Palaniappan, \& Almsafir, 2014); and is an important way to improve the efficient allocation of resources from external agents (Verrecchia 2001). "Those features and information that must be released as a result of the existence of some law or legislative stipulations, capital markets, stock-exchange commissions, or accounting authority regulations," according to mandatory disclosures (Adina \& Ion, 2010).

Additional information supplied voluntarily in addition to the obligatory information is referred to as voluntary disclosure (La Bruslerie \& Gabteni, 2012). A strong financial report, according to Damagun and Chima (2013), must not only offer users mandated disclosures, but also go the extra mile by providing voluntary disclosures to fulfill the needs of various user groups. The strategic change from traditional reporting, with greater emphasis on mandatory disclosure, is linked to the benefits attached with voluntary disclosure (Musyoka, 2017). The Financial Accounting Standard Board (FASB) (2001) identified the benefits to include reduced instances of investor misallocation of money; reduced cost of capital as a result of improved credibility and confidence relations as a result of better investment decisions; and decreased risk of litigation based on inadequate information disclosure.

Corporate performance has also been linked to voluntary intended to:
Submitted : August 08, 2021

Published : December 30, 2021

ISSN: 2507-1076

DOI: $10.24018 /$ ejbmr.2021.6.6.1042

Mudashiru A. Adebayo*

Department of Accounting, Faculty of Management Science, Lagos State University, Ojo, Nigeria.

(e-mail: adebayomuda@gmail.com) Raymond A. Ezejiofor

Department of Accountancy, Nnamdi Azikiwe University, Awka, Nigeria.

*Corresponding Author

disclosure (Oluwagbemiga, 2014). Because firms make voluntary disclosures for capital market purposes, as indicated by stock returns, this is the case (Deegan, 2010; Velashani and Mehdi, 2008; and Walter, 2006). It is against this backdrop that the present study; seeks to examine the effect of voluntary disclosure on the corporate performance of quoted manufacturing companies in Nigeria.

Studies have also been conducted on voluntary disclosure in Nigeria such as Oluwagbemiga (2014) on voluntary disclosure and financial statement quality; Avwokeni (2016) on corporate social disclosure requirement of the United Nations; and Edogiawerie and David (2016) on the relationship between voluntary disclosure and corporate performance in Nigeria. These studies however present mixed findings on the subject of inconclusive results (Musyoka, 2017; Crawford, Lont, \& Scott, 2014; Boesso \& Kumar, 2007). In developed markets like the U.S. or U.K., additional disclosure may have an incremental effect (Almeida \& Rodrigues, 2016; Verrecchia, 2001). However, this may not be the case in a developing country, such as Nigeria, with a different legal, institutional and accounting environment (Djatej, Gao, Sarikas, \& Senteney, 2009). This was supported in a recent study, when Modugu and Eboigbe (2017) established that the level of voluntary disclosure was still low despite the mandatory adoption of IFRS in the country. There is a need to evaluate the effect of voluntary disclosure on an individual country basis, which provides the impetus for the present study. Specifically, the study

1. Determine the effect of voluntary disclosure on current ratio of quoted manufacturing companies.

2. Ascertain the effect of voluntary disclosure on quick ratio of quoted manufacturing companies. 


\section{REVIEW OF RELATED LITERATURE}

Annual reports have been used to communicate the activities of firms' to various stakeholders including shareholders, financial analysts, creditors, and employees. Traditionally annual reports focused on mandatory information for shareholders however, over the years, the reporting strategy changed where most companies are disclosing over and above the minimum requirements (Wangari, 2014). There are two types of corporate disclosure: mandated and optional. Necessary disclosure is defined as "information released in order to comply with rules and regulations," whereas optional disclosure is defined as "any information disclosed in addition to the mandatory disclosure" (Shehata, 2013).

Mandatory information to be disclosed in financial statements is comprehensively spelled out in International Accounting Standards No. 1 (IAS 1), whereas voluntary disclosure refers to the discretionary release of financial and non-financial information through annual reports over and above the mandatory requirements of IAS or any other relevant accounting standard (Asava, 2013; Barako, 2007). Voluntary disclosure is defined by Meek, Roberts, and Gray (1995) as "free decisions on the part of firm management to give accounting and other information judged important to the decision needs of consumers of their annual reports." It could also include information that has been "approved by an authoritative code or body" (Hassan \& Marston, 2010).

Press releases, conference calls, investor and analyst meetings, and field visits with new and existing institutional investors are all examples of voluntary disclosure (Graham, Harvey, \& Rajgopal, 2005). A cost-benefit analysis is used to determine whether or not to freely publish information (De La Bruslerie \& Gabteni, 2010). The costs are the expenses associated with producing, certifying, and disseminating information. Opportunity costs, such as expenses associated with a loss of competitiveness or advantages, should also be considered (Verrecchia, 2003).

Theoretically, disclosure theory is based on economic explanations that information disclosure underpins agency and information difficulties, which have hampered capital markets' efficient resource allocation (Beattie, McInnes, \& Fearnley, 2004). Generally Accepted Accounting Principles (GAAPs) and International Financial Reporting Standards (IFRS) are the two most common reporting standards used by businesses (IFRS) (Achoki, Kule, \& Shukla, 2016). These guidelines do not convey all of the necessary information to investors, and as a result, there are some flaws (Schuster \& O'Connel, 2006).

\section{FinANCIAL PERFormancE}

Financial performance consists of the financial health of an organization and is merely used to compare firms from one industry to the other (Musyoka, 2017). Financial performance is usually measured using financial ratios. Financial measures are influenced by non-financial measures (Santos \& Brito, 2012). Performance can be divided into financial and non-financial performance. Eshna (2016) reported that financial performance is the "degree to which financial objectives are met", that is assessing a firm's policies and operations in monetary terms. According to Yegon (2015) the three most important decisions in a firm are: investment, financing, and dividend decisions, and are all related to firm performance.

\section{REVIEW OF EMPIRICAL STUDIES}

The impact of sustainability cost accounting on the financial performance of Nigerian telecommunication companies was studied by Udeh and Ezejiofor (2018). Time series data and an ex-post fact study design were used. With the help of SPSS Version 20.0, hypotheses were evaluated using regression analysis. As a result, the study discovered that sustainability cost accounting has had a considerable impact on Nigerian telecommunication enterprises' return on assets. Another finding is that sustainability cost accounting has significantly affected the return on equity of Nigerian telecommunication firms. In Bangladesh, Bhuyan, Lodh, and Perera (2017) investigated the impact of corporate social disclosure on firm performance. From 2011 to 2013, the sample included the top 200 companies listed on the Dhaka Stock Exchange in Bangladesh. They analyzed the data using ordinary least square and two-stage least square methods. The findings revealed a link between corporate social disclosure, ROA, market capitalization, and Tobin's Q. In Kenya, Mutiva, Ahmed, and Muiruri-Ndirangu (2017) investigated the link between voluntary disclosure and financial performance. From 2011 to 2013, the sample included 10 listed companies from the NSE 20-share index. They constructed a disclosure checklist consisting of 49 voluntarily disclosed items. They used multiple regression analysis on the data set. The study revealed that there is a strong positive relationship between voluntary disclosure and financial performance, i.e., ROI. Musyoka (2017) examined the effect of voluntary disclosure on financial performance in Nairobi. The sample comprised forty-three firms listed on the Nairobi Securities Exchange from 2006 to 2015. Firm performance was proxied using Tobin's Q. The results revealed that financial policy disclosure, financial liquidity disclosure, research, and development disclosure has a significant effect on firm performance. Investment policy disclosure and sales growth disclosure had no significant effect on firm performance. Wangari (2014) examined the effect of voluntary disclosure on financial performance in Kenya. The study adopted a descriptive research design. The sample comprised 42 commercial banks from the period 2008 to 2013. The study used secondary data from annual reports. Multiple linear regression was employed to validate the hypotheses. The study found a positive relationship between financial, forward looking and board and social disclosure and return on equity. Naran (2013) investigated the effects of voluntary disclosure and financial performance in Kenya. The study adopted a descriptive research design. The sample comprised seventeen commercial banks in Kenya. The study used secondary data from annual reports and accounts from 2008 to 2011 . The analyzed the data using multiple linear regression. The study found that financial disclosure, board disclosure and forward-looking disclosure were positive; while general and strategic disclosures are negative. Okoye 
and Ezejiofor (2013) evaluated the impact of sustainability environmental accounting on company performance and economic growth. This research looked at a variety of items, including journal publications, articles, and other pertinent information. The Pearson Product Movement Correlation Coefficient was used to evaluate and test two hypotheses in this article. As a result, the study discovered that sustainable environmental accounting has a considerable impact on business productivity, which can help companies flourish.

According to studies, with the implementation of IFRS, voluntary disclosure increases, and organizations using IAS have superior accounting quality, as indicated by less profit management, faster loss recognition, and more valuerelevant accounting numbers.

\section{Methodology}

The study made use of the ex post facto research design. The study adopts this method because it is interested in establishing the causal relationship between the dependent and independent variables; and the researcher has no direct control over the independent variables.

The population of the study comprised of twenty one (21) quoted consumer goods manufacturing firms on the Nigerian Stock Exchange (NSE). Data for the study were extracted from the annual reports and accounts of these individual companies downloaded from the websites of the companies.

\section{A. Data Analysis Techniques}

To determine the link between the independent and dependent variables, the hypotheses were examined using the regression analysis technique. This was done with the help of the E-view 9.0 at a confidence level of $5 \%$.

\section{B. Decision Rule}

If the p-value of the test statistic is less than or equal to alpha (0.05), the alternative hypotheses are accepted; if the p-value of the test statistic is larger than alpha at the 5\% significance level, the alternative hypotheses are rejected.

\section{Model Speculation}

The model for this study is stated below:

$$
\begin{aligned}
& \operatorname{CUR}_{\text {it }}=\beta_{0}+\beta_{1} \operatorname{VOD}_{\text {it }}+\beta_{2} \mathrm{FSZ}_{\text {it }}+\beta_{3} \mathrm{LEV}_{\text {it }}+\mu_{\mathrm{it}} \\
& \mathrm{QKR}_{\mathrm{it}}=\beta_{0}+\beta_{1} \mathrm{VOD}_{\text {it }}+\beta_{2} \mathrm{FSZ}_{\text {it }}+\beta_{3} \mathrm{LEV}_{\text {it }} \mu_{\mathrm{it}}
\end{aligned}
$$

where:

$\beta_{0}=$ Constant term (intercept);

$\beta_{i t}=$ Coefficients to be estimated for firm $i$ in period $t$;

$\mu_{\mathrm{it}}=$ Error term/Stochastic term for firm $i$ in period $\mathrm{t}$;

$\mathrm{CUR}_{\mathrm{t}}=$ Current ratio of firm $i$ in period $\mathrm{t}$;

$\mathrm{QKR}_{\text {it }}=$ Quick ratio of firm $\mathrm{i}$ in period $\mathrm{t}$;

$\mathrm{VOD}_{\mathrm{it}}=$ Voluntary disclosure of firm $\mathrm{i}$ in period $\mathrm{t}$;

FSIZ $_{i \mathrm{t}}=$ Firm Size of firm $i$ in period $\mathrm{t}$;

$\mathrm{LEV}_{\mathrm{it}}=$ Leverage of firm $i ́$ in period $\mathrm{t}$.

\section{Data Analysis and Interpretation}

\section{1) Test of Hypothesis One}

$\mathrm{H}_{1}$ : There is a significant effect of voluntary disclosure on current ratio of quoted manufacturing companies.

The model has a $\mathrm{R}$ squared value of.752 $\left(\mathrm{R}^{2}\right.$ quantifies the proportion of the variance in the dependent variable that is explained by the independent variables) and an Adjusted $\mathrm{R}$ squared value of 0.657 , indicating that it explains roughly 66 percent of the variance in the dependent variable. Table I shows the results.

The F-statistic (ratio of the mean regression sum of squares divided by the mean error sum of squares) was found to be 7.95, with a p-value of.05, rejecting the hypothesis that all regression coefficients are zero. However, our variable of interest, voluntary disclosure (VOD), has a t-value of 2.55 (p.05), indicating that voluntary disclosure has a positive and statistically significant association with Current Ratio; hence, the alternate hypothesis is accepted, and the null hypothesis is rejected. As a result, voluntary disclosure has a major impact on listed manufacturing businesses' current ratio.

\begin{tabular}{|c|c|c|c|c|}
\hline \multicolumn{5}{|c|}{0} \\
\hline \multicolumn{5}{|c|}{ Method: Panel EGLS (Cross-section weights) } \\
\hline \multicolumn{5}{|c|}{ Cross-sections included: 20} \\
\hline Variable & Coefficient & Std. Error & t-Statistic & Prob. \\
\hline $\mathrm{C}$ & 0.85653802175626 & 0.2090925419140917 & 4.096454201165085 & 5.101825280249397 \\
\hline VOD & 0.095570125500298 & 0.03747687624107259 & 2.550109162928563 & 0.011149456754261 \\
\hline FSZ & -2.25073568680759 & $4.927055352435666 \mathrm{e}-13$ & -4.56811528552231 & 6.606207662024522 \\
\hline LEV & -0.00026806420006 & 0.0002020271578695308 & -1.32687210414343 & 0.185325347767433 \\
\hline \multicolumn{5}{|c|}{ Weighted Statistics } \\
\hline R-squared & \multicolumn{4}{|c|}{0.7522504961588541} \\
\hline Adjusted R-squared & \multicolumn{4}{|c|}{0.6576443631272311} \\
\hline F-statistic & \multicolumn{4}{|c|}{7.95139249489679} \\
\hline Prob(F-statistic) & \multicolumn{4}{|c|}{$3.598558448310739 \mathrm{e}-06$} \\
\hline
\end{tabular}

TABLE I: REGRESSION RESULTS FOR HYPOTHESIS ONE

Source: E-views Software Ver. 9.0.

\section{2) Test of Hypothesis Two}

$\mathrm{H}_{1}$ : There is a significant effect of voluntary disclosure on a quick ratio of quoted manufacturing companies.

The model showed an $\mathrm{R}$ squared value of $0.511\left(\mathrm{R}^{2}\right.$ measures the proportion of the variance in the dependent variable that is explained by the independent variables); and Adjusted R squared value of 0.414 ; thus, the model explains approximately $41 \%$ variation in the dependent variable. The results are shown in the Table II. 
TABLE II: REGRESSION RESULTS FOR HYPOTHESIS TwO

\begin{tabular}{|c|c|c|c|c|}
\hline \multicolumn{5}{|c|}{ Dependent Variable: Quick Ratio } \\
\hline \multicolumn{5}{|c|}{ Method: Panel EGLS (Cross-section weights) } \\
\hline & Cross-sections included: & & & \\
\hline Variable & Coefficient & Std. Error & t-Statistic & Prob. \\
\hline $\mathrm{C}$ & -0.0854668311232688 & 0.249692191844325 & -0.34228876158271 & 0.7323175076205855 \\
\hline VOD & 0.1693269880727823 & 0.044431912348633 & 3.810931808295005 & 0.0001607590007391 \\
\hline FSZ & -2.865493865576643 & 1.124254699231415 & -2.54879420787443 & 0.0111908761012931 \\
\hline LEV & -0.0004929303180807 & 0.0013440055808733 & -0.36676210656835 & 0.7139948715622658 \\
\hline \multicolumn{5}{|c|}{ Weighted Statistics } \\
\hline R-squared & \multicolumn{4}{|c|}{0.511134863460978} \\
\hline Adjusted R-squared & \multicolumn{4}{|c|}{0.414062074340373} \\
\hline F-statistic & \multicolumn{4}{|c|}{5.265480348215205} \\
\hline Prob(F-statistic) & \multicolumn{4}{|c|}{0.000385917469791} \\
\hline
\end{tabular}

Source: E-views Software Ver. 9.0.

The $\mathrm{F}$ statistic (ratio of the mean regression sum of squares divided by the mean error sum of squares) was found to be 5.27, with a p-value of 0.05 , rejecting the hypothesis that all regression coefficients are zero. Our variable of interest, voluntary disclosure (VOD), has a tvalue of 3.81 ( $p$ 0.05), indicating that VOD has a positive and statistically significant association with Quick Ratio; consequently, the alternate hypothesis is accepted, and the null hypothesis is rejected. As a result, voluntary disclosure has a major impact on the quick ratio of quoted consumer products manufacturing firms in Nigeria.

\section{DISCUSSION OF FINDINGS}

The thrust of the current study is on examining the effect of voluntary disclosure on the corporate performance of manufacturing firms. Generally, the study finds a strong positive relationship between voluntary disclosure and corporate performance, more specifically on profitability and liquidity. This is in line with Hamrouni, Miloudi, and Benkraiem (2015) in France; when they demonstrated that there is a direct and significant relationship between disclosure indexes and performances. Also, Musyoka (2017) in Nairobi; revealed that financial policy disclosure, financial liquidity disclosure, research, and development disclosure had a significant positive relationship with firm performance. Voluntary disclosure has a significant negative effect on net profit margin of quoted manufacturing companies. But had a significant positive effect on measures of liquidity, i.e., the current ratio and quick ratio. Another interesting finding was the effect of firm size in the models, it was significant for Quick Ratio. However, it was not for Current Ratio. Lynch, Pownall, and Simko (2011) in the U.S. showed that larger firms were more likely to disclose revenue growth as results of increased disclosure and transparency demands from the shareholders.

\section{CONCLUSION AND RECOMMENDATIONS}

The study was undertaken to examine the effect of voluntary disclosure on corporate performance of quoted manufacturing companies in Nigeria. In 2010, the Federal Government of Nigeria, through its Federal Executive Council (FEC), accepted the recommendations of the Committee on the Roadmap to the Adoption of International
Financial Reporting Standards (IFRS) in Nigeria, which stated that adopting IFRS would be in the best interests of the Nigerian economy. The IFRS Adoption Roadmap was stipulated in three phases, with mandatory dates from manufacturing firms stipulated in 2012. IFRS therefore became the official framework for financial reporting in the country to guide the preparation and presentation of financial statements. Following this, studies have shown the effect of IFRS adoption on financial ratios and accounting quality. However, the literature on voluntary disclosure still remains scanty. The study makes the following recommendations:

A sustained effort at creating a harmonised framework for voluntary disclosure is encouraged by policy makers. The framework should be designed in line with the peculiarities of each sector; this is because the relevance of items in the framework may vary across sectors. To further strengthen corporate governance practices among firms, there should be strict enforcement of NSE sustainability disclosure guidelines for manufacturing firms.

\section{REFERENCES}

Abraham, S., \& Tonks, I. (2006). Voluntary corporate disclosure by UK companies. Working paper, University of Exeter. Retrieved from https://dspace.stir.ac.uk/bitstream/1893/10388/1/The\%20Importance $\% 20$ of\% 20Corporate\%20Environmental\%20Reputation\%20to\%20In vestors.pdf.

Achoki, I., Kule, W. J., \& Shukla, J. (2016). Effect of voluntary disclosure on the financial performance of Commercial banks in Rwanda. A study on selected banks in Rwanda'. European Journal of Business and Social Sciences, 5(06), 167-184

Adina, P., \& Ion, P. (2010). Aspects regarding corporate mandatory and voluntary disclosure. Retrieved from: http://gorganiau.ac.ir/my_doc/gorgan/professor/m.maatoofi/ADS2.pdf

Alhazaimeh, A., Palaniappan, R., \& Almsafir, M. (2014). The impact of corporate governance and ownership structure on voluntary disclosure in annual reports among listed Jordanian companies. Procedia-Social and Behavioral Sciences, 129, 341-348.

Almeida, J. E. F. D., \& Rodrigues, H. S. (2016). Effects of IFRS, Analysts, and ADR on Voluntary Disclosure of Brazilian Public Companies. Journal of International Accounting Research, 16(1), 21-35.

Asava, K. I. (2013). The Effect of Voluntary Disclosure on Stock Returns of Companies Listed at the Nairobi Securities Exchange (Unpublished Master's Thesis). University of Nairobi.

Avwokeni, A. J. (2016). Does IFRS Detract from Social Disclosure in Corporate Annual Report Aand Accounts? Evidence from Nigeria. Acta Universitatis Danubius. Economica, 12(5).

Barako, D. G. (2007). Determinants of voluntary disclosures in Kenyan companies annual reports. African Journal of Business Management, 1(5), 113-128.

Barth, M. E., Landsman, W. R., \& Lang, M. H. (2008). International Accounting Standards and Accounting Quality. Journal of Accounting 
Research, 46(3), 467-498.

Beattie, V., McInnes, B., \& Fearnley, S. (2004). A methodology for analysing and evaluating narratives in annual reports: a comprehensive descriptive profile and metrics for disclosure quality attributes. Accounting forum, 28(3), 205-236.

Bhuyan, M., Lodh, S. C. \& Perera, N. (2017). The effects of corporate social disclosure on firm performance: empirical evidence from Bangladesh. 2017 Accounting and Finance Association of Australia and New Zealand Conference (pp. 1-36). Accounting and Finance Association of Australia and New Zealand.

Boesso, G., \& Kumar, K. (2007). Drivers of corporate voluntary disclosure. Accounting, Auditing \& Accountability Journal, 20(2), 269-296.

Crawford, L., Lont, D., \& Scott, T. (2014). The effect of more rules-based guidance on expense disclosure under International Financial Reporting Standards. Accounting \& Finance, 54(4), 1093-1124.

Damagun, Y. M., \& Chima, E. (2013). The impact of corporate governance on voluntary information disclosures of quoted firms in Nigeria: An empirical analysis. Research Journal of Finance and Accounting, 4(13), 166-179.

Deegan, C. (2010). Social responsibility disclosure practices. The Accounting Review, 68-89.

De La Bruslerie, H., \& Gabteni, H. (2010, June). Voluntary financial disclosure, the introduction of IFRS and long-term communication policy: An empirical test on French firms. In 17th Multinational Financial Society (MFS) Meeting at Barcelona, Spain.

Djatej, A., Gao, G., Sarikas, R., \& Senteney, D. (2009). An investigation of the comparative impact of degree of implementation of IFRS upon the public and private information quality of East and West European firms. Advances in Accounting, incorporating Advances in International Accounting, 25, 208-215.

Edogiawerie, O. U., \& David, J. O. (2016). Financial reporting and voluntary disclosure in Nigeria quoted companies. Igbinedion University Journal of Accounting, 1, 42-58.

Eshna, S., (2016, August 27). Financial performance - Understanding its concepts and importance. Retrieved from http://www.simplilearn.com/financialperformance-rar21-article.

Financial Accounting Standards Board (2001). Improving Business Reporting: Insights into Enhancing Voluntary. Available at https://www.fasb.org/brrp/brrp2.shtml.

Graham, J. R., Harvey, C. R., \& Rajgopal, S. (2005). The economic implications of corporate financial reporting. Journal of Accounting and Economics, 40(1-3), 3-73.

Hassan, O., \& Marston, C. L. (2010). Disclosure measurement in the empirical accounting literature-a review article. 15 July 2010. Recuperado em, 12. Available at: http://bura.brunel.ac.uk/bitstream/2438/5047/1/1018\%5B1\%5D.pdf.

La Bruslerie, H., \& Gabteni, H. (2012). Voluntary disclosure vs. mandatory disclosure: The case of IFRS introduction on European firms. SSRN Working Paper. Available at: http://papers.ssrn.com/sol3/papers.cfm? abstract_id= 2010326 .

Meek, G.K., Roberts, C.B., \& Gray, S.J. (1995).Factors influencing voluntary annual report disclosures by U.S., U.K. and Continental European multinational corporations. Journal of International Business Studies, 26(3), 555-572. http://dx.doi.org/10.1057/palgrave.jibs.8490186.

Modugu, K.P., \& Eboigbe, S.U. (2017). Corporate Attributes and Corporate Disclosure Level of Listed Companies in Nigeria: A Post-IFRS Adoption Study. Journal of Finance and Accounting, 5(2), 44-52. Available at http://pubs.sciepub.com/jfa/ $/ 2 / 3$.

Musyoka, M. N. (2017). Effect of Voluntary Disclosure on Financial Performance of Firms Listed at Nairobi Securities Exchange (Unpublished Master's Thesis). School of Business and Public Management at KCA University.

Mutiva, J. M., Ahmed, A. H., \& Muiruri-Ndirangu, J. M. (2017). The relationship between voluntary disclosure and financial performance of selected companies quoted at the Nairobi Securities exchange. International Journal of Managerial Studies and Research (IJMSR), 3(6), 171-195.

Naran, P. M. (2013). The Effect of Company Size and Voluntary Disclosure on Financial Performance of Commercial Banks in Kenya (Unpublished MBA thesis). Nairobi: University of Nairobi.

Okoye P.V.C. \& Ezejiofor, R. A. (2013). An appraisal of sustainability environmental accounting in enhancing corporate productivity and economic performance. ISSN NO 2320-5407 International Journal of Advanced Research 1(8), 685-693. Journal homepage: http://www.journalijar.com.

Oluwagbemiga, E. O. (2014). The use of voluntary disclosure in determining the quality of financial statements: Evidence from the Nigeria listed companies. Serbian Journal of Management, 9(2), 263280.
Santos, J. B., \& Brito, L. A. L. (2012). Toward a Subjective Measurement Model for Firm Performance. Brazilian Administration Review.

Schuster, P., \& O'Connel, V. (2006). The trend toward voluntary corporate disclosures. Management Accounting Quarterly, 7(2), 1-9.

Shehata, N. F. (2013). Theories and determinants of voluntary disclosure. Accounting and Finance Research, 3(1), p. 18.

Shehata, N. (2013). Corporate governance disclosure in the Gulf countries (Doctoral dissertation). Aston University.

Solomon, J. (2013). Corporate governance and accountability. United Kingdom: John Wiley \& Sons.

Udeh, \& Ezejiofor, R. A. (2018). Effect of sustainability cost accounting on financial performance of telecommunication firms in Nigeria. Journal for Studies in Management and Planning. 4(6); ISSN: 2395-0463 Available at: http://edupediapublications.org/journals/index.php/JSMaP.

Velashani, M. A., \& Mehdi, A. (2008). The economic benefits of voluntary disclosure with particular reference to environmental disclosure. Monash Business Review, 4(2), 1-8.

Verrecchia, R. E. (2003). Why all the hoopla about Enron? Journal of Accounting and Public Policy, 22(2), 99-105.

Verrecchia, R. E. (2001). Essays on disclosure. Journal of Accounting \& Economics, 32, 97-180.

Walter, A. (2006). Intra-industry imitation in corporate environmental reporting: An international perspective. Journal of Accounting and Public Policy, 25(3), 299-331.

Wangari, M. N. (2014). The Effect of Voluntary Disclosure on the Financial Performance of Commercial Banks in Kenya (Unpublished Master's Thesis). University of Nairobi.

Wanjau, G. M. (2015). The Effect of Voluntary Disclosures on the Stock Returns of Firms Listed at the Nairobi Securities Exchange (Unpublished Master's Thesis). University of Nairobi.

Yegon, C. K. (2015). Effect of Enterprise Risk Management Determinants on Financial Performance of Listed Firms in Kenya (Unpublished Master's Thesis). University of Nairobi. 